\title{
DECOMPOSITION OF WHEAT STRAW AND STABILIZATION OF MICROBIAL PRODUCTS
}

\author{
R. P. VORONEY' ${ }^{1}$, E. A. PAUL ${ }^{2}$, and D. W. ANDERSON ${ }^{3}$ \\ ${ }^{\prime}$ Department of Land Resource Science, University of Guelph, Guelph, Ontario, \\ Canada NIG 2WI; ${ }^{2}$ Department of Crop and Soil Science, Michigan State University, \\ East Lansing, MI, 48824, U.S.A.; and ${ }^{3}$ Department of Soil Science, University of \\ Saskatchewan, Saskatoon, Saskatchewan, Canada S7N 0W0. Received 3 Dec. 1987, \\ accepted 13 Sept. 1988.
}

Voroney, R. P., Paul, E. A. AND Anderson, D. W. 1989. Decomposition of wheat straw and stabilization of microbial products. Can. J. Soil Sci. 69: 63-77.

This research examined the effects of soil environment on the decomposition of cereal crop residues and stabilization of microbial products in the field. Microplots at semiarid and subhumid field sites were amended with ${ }^{14} \mathrm{C}-{ }^{15} \mathrm{~N}$-labelled wheat straw and with ${ }^{14} \mathrm{C}$-labelled glucose plus ${ }^{15} \mathrm{~N}$-labelled $\mathrm{NH}_{4} \mathrm{NO}_{3}$ and the fate of the residual $\mathrm{C}$ and $\mathrm{N}$ was monitored over $10 \mathrm{yr}$. Mineralization of $\mathrm{C}$ and $\mathrm{N}$ derived from wheat straw was greater at the site in the more moist environment in the short term ( $2 \mathrm{yr})$. In the long term (up to $10 \mathrm{yr}$ ), however, the residual $\mathrm{C}$ and $\mathrm{N}$ at this site decayed at a slightly slower rate, providing evidence of stabilization of organic material in chemically resistant forms, as compared to possible physical protection in the semi-arid clay-textured soil. The total recovery of labelled $\mathrm{N}$ was $22.5-24 \%$ in the harvested crops with $13.4-16 \%$ remaining in the surface soil by the end of the study. Mineralized labelled organic $\mathrm{N}$ was used with an efficiency ranging from 32 to $51 \%$. However, after summer fallow the crop apparently used mineralized labelled $\mathrm{N}$ with an efficiency of only $7 \%$. This study showed that moistness of the soil environment has a considerable effect on residue decomposition. Stabilization of humic material derived from residues relates more to the recalcitrance of microbial products and their interactions with soil mineral colloids than to the nature of the original residue.

Key words: Mineralization rates, crop residues, microbial turnover, chemical recalcitrance, physical protection, plant $\mathrm{N}$ use-efficiency

[Décomposition de la paille de blé et stabilisation des produits microbiens.] Titre abrégé: Décomposition des résidus de culture.

Nous avons étudié les effets de l'environnement du sol sur la décomposition des résidus de cultures céréalières et sur la stabilisation des produits microbiens au champ. Des micro-parcelles situées en régions semi-arides ou subhumides ont été traitées avec de la paille de blé marquée au $\mathrm{C}-14$ et au $\mathrm{N}-15$, et avec du glucose marqué au $\mathrm{C}-14$ et additionné de $\mathrm{NH}_{4} \mathrm{NO}_{3}$ marqué au $\mathrm{N}-15$. Le devenir du $\mathrm{C}$ et du $\mathrm{N}$ résiduels a ensuite été étudié sur une période de 10 années. La minéralisation du $\mathrm{C}$ et du $\mathrm{N}$ dérivés de la paille de blé était plus grande, à court terme ( 2 ans), dans les parcelles caractérisées par un environnement plus humide. A long terme (jusqu'à 10 ans), toutefois, la décomposition du $\mathrm{C}$ et du $\mathrm{N}$ résiduels à cet endroit a été légèrement moins rapide, laissant conclure à une stabilisation de la matère organique sous des formes chimiquement résistantes, comparativement à une possible protection physique dans le sol argileux des régions semi-arides. La récupération totale du $\mathrm{N}$ marqué a atteint 22,5 à $24 \%$ dans les cultures récoltées, une proportion de 13,4 à $16 \%$ demeurant à la surface du sol à la fin de l'étude. Le $\mathrm{N}$ organique marqué minéralisé a été utilisé avec un efficacité variant de 32 à $51 \%$. Toutefois, après la jachère d'été, les cultures ont apparemment utilisé le $\mathrm{N}$ marqué minéralisé avec une efficacité de 7\% seulement. Cette étude a permis

Can. J. Soil Sci. 69: 63-77 (Feb. 1989) 
de constater que l'humidité du sol a un effet considérable sur la décomposition des résidus. La stabilisation de la matière humique dérivée des résidus dépend plus du caractère "récalcitrant" des produits microbiens et de leurs interactions avec les colloïdes minéraux du sol que de la nature des résidus originaux.

Mots clés: Taux de minéralisation, résidus de culture, renouvellement microbien, produits "récalcitrants", protection physique, efficacité d'utilisation de l'azote

Plant residues are a major source of energy and nutrients for use by heterotrophic microorganisms in agroecosystems, and affect the biological, chemical and physical properties of the soil. Growth of the microbial biomass on residues enhances turnover of soil organic matter through concurrent immobilization, mineralization and stabilization reactions. This fundamental process maintains plant nutrient cycling and is important for the longterm conservation of soil organic matter through production of the precursors of humic substances. Formation of organic stabilizing materials for soil structure is primarily dependent on the input of crop residues together with soil management practices.

The production of ${ }^{14} \mathrm{C}$-, ${ }^{15} \mathrm{~N}$-labelled plant residues has made it possible to trace added plant material in soil. Rates of decomposition of isotope-labelled crop residues in soils have been estimated in a number of studies involving a wide variety of plant materials and soil types in both laboratory and natural environmental conditions (Jenkinson 1965, 1971, 1977a, b; Biederbeck 1966; Fuhr and Sauerbeck 1968; Oberlander and Roth 1968; Smith and Douglas 1971; Sauerbeck et al. 1972; Oberlander 1973; Shields and Paul 1973; Sauerbeck and Gonzalez 1977; Jenkinson and Ayanaba 1977; Amato and Ladd 1980; Ladd et al. 1981, 1983, 1985; Amato et al. 1984; Christensen 1986).

The decomposition process can be described in two parts: the initial rapid mineralization of added substrates and derived microbial cells accounting for $60-80 \%$ of the added C (Jenkinson 1965, 1977b; Scott et al. 1983), followed by the slower mineralization of stabilized microbial products and undecomposed material (Oberlander and Roth 1968; Amato and Ladd 1980). This characteristic pattern of decomposition has been confirmed in a number of field and laboratory studies in soils amended with: (1) simple substrates such as glucose and acetate, (2) chemically separated fractions of plant material including cellulose, hemi-cellulose and lignin, and (3) complex substrates such as crop residues and microbial constituents.

Rates of initial decomposition vary widely depending on climatic conditions, in particular moisture and temperature regimes. The slowest rates have been reported for Saskatchewan grasslands, which are affected by extended periods of drought and frost (Shields and Paul 1973), and for northeast Austria, which also experiences drastic temperature fluctuations and prolonged periods of drought (Oberlander and Roth 1968). Observations in southeast England (Jenkinson 1977b), in an area with moderate temperature and with precipitation distributed evenly throughout the year, approximated those made in northeast Germany (Sauerbeck and Fuhr 1968) which has a similar climate. Jenkinson and Ayanaba (1977) have reported that decomposition of ryegrass in tropical forest soils of Nigeria proceeded four times as fast as in southeast England. Somewhat similar results were obtained by Sauerbeck and Gonzalez (1977) for labelled wheat straw decomposing for $1 \mathrm{yr}$ in 12 different Costa Rican soils. Ladd et al. (1981a) reported that the average rate of breakdown of legume residues (medic) in south Australian soils during the rapid decomposition phase was similar to the data obtained by Jenkinson and Ayanaba, whereas the slow decomposition phase was similar to that established in temperate climates (Jenkinson 1977b).

During the initial stage of decomposition, the structure and composition of the intact plant residue, which varies with age and species, limit the rate of loss of residue $\mathrm{C}$ from 
the soil. Lespinat et al. (1976) reported that plant parts, including stems and leaves, decomposed at significantly different rates during the first 2 wk but after that there were no significant differences in $\mathrm{C}$ mineralized. Waksman and Tenny (1927) showed that immature plant material, containing a large water-soluble fraction decomposed more rapidly than mature material. Oberlander (1973) reported that fresh green maize decomposed more rapidly than dried green maize or mature wheat straw. The water-soluble fraction, including sugars, starch, organic acids and proteins, is readily utilized followed by fats, waxes, resins and oils (Reber and Schara 1971; Parr and Papendick 1978). Hemicellulose and cellulose decompose more slowly, followed by lignin and other phenolic compounds. Herman et al. (1977) reported that the decomposition of roots of different native grass species was controlled by the $C: N$ ratio of the roots, together with their lignin and carbohydrate contents.

By the end of $1 \mathrm{yr}$, most crop residue constituents have decomposed and would be present as living microorganisms and stabilized microbial products (Oberlander 1973; Shields and Paul 1973; Sauerbeck 1976; Jenkinson 1977b). However, lignin, the most resistant of the major plant constituents, decomposes slowly in soil (Jenkinson and Tinsley 1959) and $<20 \%$ would have mineralized during this period (Stott et al. 1983). Part of the residual decomposition products, autolyzed microbial cells and the extracellular metabolites of microorganisms, may undergo oxidation reactions resulting in the formation of humic substances (Sorensen 1967; Wang et al. 1983). At all stages of degradation prior to ring cleavage, lignin fractions and other aromatic compounds are subject to polymerization reactions with resistant humic constituents (Kassim et al. 1982; Martin et al. 1982; Stott et al. 1983).

Most field studies of crop residue decomposition have been of short duration, resulting in a lack of data on the long-term stabilization of crop residue derived $\mathrm{C}$ and $\mathrm{N}$. The objective of this study was to examine the net mineralization of $\mathrm{C}$ and $\mathrm{N}$ derived from the decomposition of cereal crop residues and stabilized microbial products under different climatic conditions over a short term (months) and in the long term (years).

\section{MATERIALS AND METHODS}

\section{Soils}

Field studies of the decomposition of cereal crop residues began in 1968 and were maintained for 10 yr on a Sceptre clay and a Waitville loam (Table 1). Further studies utilizing glucose and cereal straw amendments were started in 1971 on the Sceptre site (7-yr study). The general climatic conditions prevailing at the field sites are markedly different. The Sceptre site has less seasonal precipitation, a higher mean water deficit and a longer growing season than the cooler, more humid Waitville site.

\section{Establishment of Field Sites}

Four replicate plots, 3- $\mathrm{m}^{2}$, were set out on fallow fields of level topography and the agricultural practices of the area were simulated for the 10-yr study. Microplots to contain the labelled crop residues were prepared by pressing aluminum cylinders ( $30 \mathrm{~cm}$ diameter $\times 25 \mathrm{~cm}$ length) into the center of each plot to a depth of $20 \mathrm{~cm}$ (McGill 1971; Shields 1972). Wheat residues were incorporated into the plough layer soil in July. The upper $15 \mathrm{~cm}$ of soil was removed from the microplots, composited, mixed well and passed through a 6-mm sieve. Weighed portions of moist soil were mixed with labelled wheat straw $(16.35 \mathrm{~g}$ residue in $8.283 \mathrm{~kg}$ Sceptre soil and $16.35 \mathrm{~g}$ in $8.697 \mathrm{~kg}$ Waitville soil (oven-dry basis)) and returned to the microplots. The initial concentrations of labelled $\mathrm{C}$ and $\mathrm{N}$ in the microplots were $756 \mu \mathrm{g} \mathrm{C}$ and $37.1 \mu \mathrm{g} \mathrm{N} \mathrm{g}^{-1}$ soil at the Sceptre site and $720 \mu \mathrm{g} \mathrm{C}$ and $35.3 \mu \mathrm{g} \mathrm{N} \mathrm{g}^{-1}$ soil at the Waitville site.

The plots and microplots were maintained in bare fallow during the remainder of the first growing period and the cropping sequence started the following spring (Table 2). The microplots and plots were seeded to wheat at $100 \mathrm{~kg} \mathrm{ha}^{-1}$ (22 seeds per microplot) and managed following conventional practices.

In 1971, four additional microplots were established at the Sceptre site to compare crop residue decomposition under fallow to that under crop using a similar technique. Wheat had been grown on the site during the previous year and the plough 
Table 1. Selected soil properties and climatic conditions at field sites

\begin{tabular}{|c|c|c|}
\hline Parameters & Sceptre clay & Waitville loam \\
\hline \multicolumn{3}{|l|}{ Soil } \\
\hline $\begin{array}{l}\text { Nearest town in } \\
\text { Saskatchewan }\end{array}$ & Matador & Nut Mountain \\
\hline Location & SW28-20-13-3rd & SW4-38-10-2nd \\
\hline Great group $\dagger$ & $\begin{array}{l}\text { Rego Brown Chernozem } \\
\text { (Andic Boroll) }\end{array}$ & $\begin{array}{l}\text { Dark Gray Luvisol } \\
\text { (Boralfic Boroll) }\end{array}$ \\
\hline Soil association & Sceptre & Waitville \\
\hline $\mathrm{C}(\%)$ & 2.73 & 2.46 \\
\hline $\mathrm{N}(\%)$ & 0.24 & 0.21 \\
\hline $\begin{array}{l}\text { Natural }{ }^{15} \mathrm{~N} \text { atom } \% \\
\text { abundance (Kjeldahl } \mathrm{N})\end{array}$ & 0.3722 & 0.3702 \\
\hline Sand $(\%)$ & 9.8 & 32.3 \\
\hline Silt $(\%)$ & 40.2 & 45.5 \\
\hline Clay $(\%)$ & 49.0 & 22.2 \\
\hline \multicolumn{3}{|l|}{ Climate $\neq$} \\
\hline \multicolumn{3}{|l|}{ Temperatures $\left({ }^{\circ} \mathrm{C}\right)$} \\
\hline July mean & 19.4 & 17.2 \\
\hline January mean & -14.4 & -19.4 \\
\hline Degree-days above $5^{\circ} \mathrm{C}$ & 1526 & 1110 \\
\hline Frost-free period (d) & 110 & 80 \\
\hline Growing season & 18 Apr.-16 Oct. & 30 Apr. -7 Oct. \\
\hline \multicolumn{3}{|l|}{ Moisture $(\mathrm{cm})$} \\
\hline Annual precipitation & 33 & 43 \\
\hline May-Sept. precipitation & 20 & 28 \\
\hline Potential evapotranspiration & 58 & 51 \\
\hline Annual water deficiency & 23 & 13 \\
\hline
\end{tabular}

$\dagger$ Great group of the well-drained member from each soil association.

$\$$ Estimated from data in Chapman and Brown (1966).

Table 2. Cropping sequence

\begin{tabular}{|c|c|c|c|c|c|c|c|c|c|c|c|}
\hline & \multicolumn{11}{|c|}{ Crop year } \\
\hline & 1 & 2 & 3 & 4 & 5 & 6 & 7 & 8 & 9 & 10 & 11 \\
\hline \multicolumn{12}{|l|}{ Ten-year } \\
\hline $\begin{array}{l}\text { Sceptre clay } \\
\text { Waitville loam }\end{array}$ & $\begin{array}{l}\mathrm{F} \dagger \\
\mathrm{F}\end{array}$ & $\begin{array}{l}\mathrm{W} \ddagger \\
\mathbf{W}\end{array}$ & $\begin{array}{l}\text { W } \\
\text { W }\end{array}$ & $\begin{array}{l}\text { W } \\
\text { W }\end{array}$ & $\begin{array}{l}\text { W } \\
\text { W }\end{array}$ & $\begin{array}{l}\mathbf{F} \\
\mathbf{F}\end{array}$ & $\begin{array}{l}\text { W } \\
\mathbf{W}\end{array}$ & $\begin{array}{l}\text { W } \\
\mathbf{W}\end{array}$ & $\begin{array}{l}\mathbf{F} \\
\mathbf{W}\end{array}$ & $\begin{array}{l}\text { W } \\
\text { W }\end{array}$ & $\begin{array}{l}\mathbf{W} \\
\mathbf{W}\end{array}$ \\
\hline \multicolumn{12}{|c|}{ Seven-year (Sceptre clay) } \\
\hline $\begin{array}{l}\text { Crop residues } \\
\text { Microbial products }\end{array}$ & & & & $\begin{array}{l}\mathbf{F} \\
\mathbf{W}\end{array}$ & $\begin{array}{l}\mathbf{W} \\
\mathbf{W}\end{array}$ & $\begin{array}{l}\mathbf{F} \\
\mathbf{F}\end{array}$ & $\begin{array}{l}\text { W } \\
\mathbf{W}\end{array}$ & $\begin{array}{l}\text { W } \\
\text { W }\end{array}$ & $\begin{array}{l}F \\
F\end{array}$ & $\begin{array}{l}\text { W } \\
\text { W }\end{array}$ & $\begin{array}{l}\text { W } \\
\mathbf{W}\end{array}$ \\
\hline
\end{tabular}

$\uparrow$ Fallow.

\$ Wheat crop.

layer soil was undisturbed prior to initiation of the experiment in spring (May). Microplots were amended with wheat straw $(1007 \mathrm{mg} \mathrm{C}$ and $49.4 \mathrm{mg} \mathrm{N} \mathrm{g}^{-1}$ soil) in early June. During the first season one-half of the microplots were cropped to wheat while the remaining microplots were fallowed. The microplots were treated similarly for the remainder of the study (Table 2).

Duplicate microplots were also set out in the fallowed plots to study the decomposition of microbial products. Labelled microbial biomass was produced in situ by adding ${ }^{14} \mathrm{C}$-labelled glucose $\left(4.33 \mathrm{~Bq}{ }^{14} \mathrm{C} \mu \mathrm{g}^{-1} \mathrm{C}\right.$ ) and ${ }^{15} \mathrm{~N}$-labelled ${ }^{15} \mathrm{NH}_{4}$ ${ }^{15} \mathrm{NO}_{3}\left(5.4282{ }^{15} \mathrm{~N}\right.$ atom \% abundance) at rates of $937 \mu \mathrm{g} \mathrm{C} \mathrm{g}^{-1}$ soil and $37.3 \mu \mathrm{g} \mathrm{N} \mathrm{g}^{-1}$ soil, respectively.

\section{Field Sampling Procedures and Analyses}

Soil samples were taken in the spring prior to seeding and in the late fall after harvesting. A 
representative sample of the soil in each microplot, approximately $100 \mathrm{~g}$, was obtained by removing all of the labelled soil and passing it through a $2-\mathrm{mm}$ sieve. Samples were maintained at ambient temperature during transportation to the laboratory and were frozen $\left(-40^{\circ} \mathrm{C}\right)$ within $12 \mathrm{~h}$ of being taken. In preparation for $\mathrm{C}$ and $\mathrm{N}$ analyses, the soil was freeze-dried and ground to finer than 100 mesh.

The aboveground crop was harvested near maturity in mid-August. Plant samples were oven-dried $\left(60^{\circ} \mathrm{C}\right)$, threshed and ground to finer than 60 mesh for analysis.

Production of ${ }^{14} \mathrm{C}$-, ${ }^{15} \mathrm{~N}$-labelled Wheat Straw Labelled wheat straw residues were produced from plants grown to seed set ( $90 \mathrm{~d}$ ) in a growth chamber containing soil fertilized with $\mathrm{K}^{15} \mathrm{NO}_{3}$ and an atmosphere enriched with ${ }^{14} \mathrm{CO}_{2}$. The growth chamber consisted of a clear plexiglass canopy (75 $\mathrm{cm}$ diameter $\times 85 \mathrm{~cm}$ high) sealed to a metal base $(20 \mathrm{~cm}$ high) that contained the soil. A gas circulation system was connected to the growth chamber to maintain a constant atmospheric concentration of $\mathrm{CO}_{2}$ of uniform specific activity. The harvested wheat straw residues contained $2.96 \mathrm{~Bq}{ }^{14} \mathrm{C} \mu \mathrm{g}^{-1} \mathrm{C}$ and $3.9072{ }^{15} \mathrm{~N}$ atom \% abundance; the $C: N$ ratio was $20.3: 1$, considerably narrower than that of mature field grown wheat crop residues (80-140:1). The wheat straw was chopped to $<2.5 \mathrm{~cm}$ prior to addition to the soil.

\section{Analytical Procedures}

Total $\mathrm{C}$ in soil was determined by dry combustion (McKeague 1976) modified to allow measurement of the ${ }^{14} \mathrm{C}$ content. The $\mathrm{CO}_{2}$ liberated upon combustion of the soil $\mathrm{C}$ was absorbed in $0.5 \mathrm{M} \mathrm{NaOH}$. After sample combustion and prior to washing the $\mathrm{NaOH}-\mathrm{CO}_{2}$ absorption tower, duplicate 1-mL samples of $\mathrm{NaOH}$ scrubbing solution were taken for ${ }^{14} \mathrm{C}$ analysis, which was done by liquid scintillation counting. Unreacted $\mathrm{NaOH}$ was titrated with standardized $\mathrm{HCl}$ using phenolphathalein as an indicator after precipitating the carbonate with $\mathrm{BaCl}_{2}$. More than $96 \%$ of the $\mathrm{C}$ in standards was recovered by this procedure.

The sample of $\mathrm{NaOH} / \mathrm{Na}_{2}{ }^{14} \mathrm{CO}_{3}$ was placed in a glass scintillation vial together with $1 \mathrm{~mL}$ dionized water and $20 \mathrm{~mL}$ scintillation cocktail (Scintiverse, Fisher), sealed with a foil-backed plastic cap and swirled in a vortex mixer until clear. Samples were dark-adapted for $12 \mathrm{~h}$ and counted in a Beckman LS 9000 liquid scintillation spectrometer set to count each sample to a $2 \sigma$ level of $2 \%$, or for $10 \mathrm{~min}$.

Analysis of total $\mathrm{N}$ was conducted on soil and plant samples using a modified version of the semimicro Kjeldahl technique (Bremner 1965). Organic $\mathrm{N}$ was converted to the ammonium form by heating in a block digestor for $4 \mathrm{~h}$ at a temperature of $360^{\circ} \mathrm{C}$. Ten millilitres $18 \mathrm{M} \mathrm{H}_{2} \mathrm{SO}_{4}, 3 \mathrm{~g}$ powered $\mathrm{K}_{2} \mathrm{SO}_{4}: \mathrm{CuSO}_{4} 5 \mathrm{H}_{2} \mathrm{O}$ (30:1 by weight) and a selenium catalyst in the form of one selenized Hengar granule were used in the digestion of each sample. After dilution, the ammonia was liberated from digests by the addition of $40 \% \mathrm{NaOH}$ (wt/vol) and steam distilled into $4 \%$ alcoholic boric acid (wt/vol). Cross contamination was avoided by distilling $20 \mathrm{~mL}$ of $95 \%$ ethanol (wt/vol) after each sample to flush the distillation head and condenser. The distillates were titrated with $0.05 \mathrm{M} \mathrm{H}_{2} \mathrm{SO}_{4}$ to $\mathrm{pH} 4.8$.

For measurement of ${ }^{15} \mathrm{~N}$ atom $\%$ abundance, the titrated samples were concentrated to $<1 \mathrm{~mL}$ in an oven at $60^{\circ} \mathrm{C}$. The samples were then transferred to a vial $(15 \mathrm{~mm} \times 85 \mathrm{~mm}$ pyrex culture tubes), using a disposable Pasteur pipette, and oven-dried $\left(60^{\circ} \mathrm{C}\right)$. The dried $\mathrm{NH}_{4}{ }^{+}-\mathrm{N}$ salt was converted to $\mathrm{N}_{2}$ using a modification of the conversion system described by Porter and O'Deen (1977). The sample vial was attached to a high vacuum manifold unit and evacuated. Lithium hypobromite ( $\mathrm{LiOBr}$ ) was added to oxidize the $\mathrm{NH}_{4}{ }^{+}$to $\mathrm{N}_{2}$ (Ross and Martin 1970). The gaseous sample was transferred, using a Toepler pump, to a gas storage bulb. These vessels were then attached to the inlet manifold of the Micromass 602E mass spectrometer.

\section{Data Representation and Statistical Analysis}

The residue decomposition curves were analyzed assuming: (i) that the process could be represented by a series of independently decaying components, and (ii), that first-order reaction rate kinetics were followed. Sequential curve peeling was used to obtain the sizes of the individual components and their specific decay rate constants. The data were first plotted as in (percent labelled residue remaining) against time. The long-term data points were in a straight line: extension of the line back to intercept with the $y$ axis gave the size of the component: its decay rate constant was obtained from the slope. To obtain the decay rate constant of the second component (and its size), values describing the straight line were subtracted from the respective data points on the curve and the difference plotted, giving a second straight line. The fact that this second plot was linear indicates that a two component model was adequate for describing the decomposition process.

Statistical analysis of the data was done by 


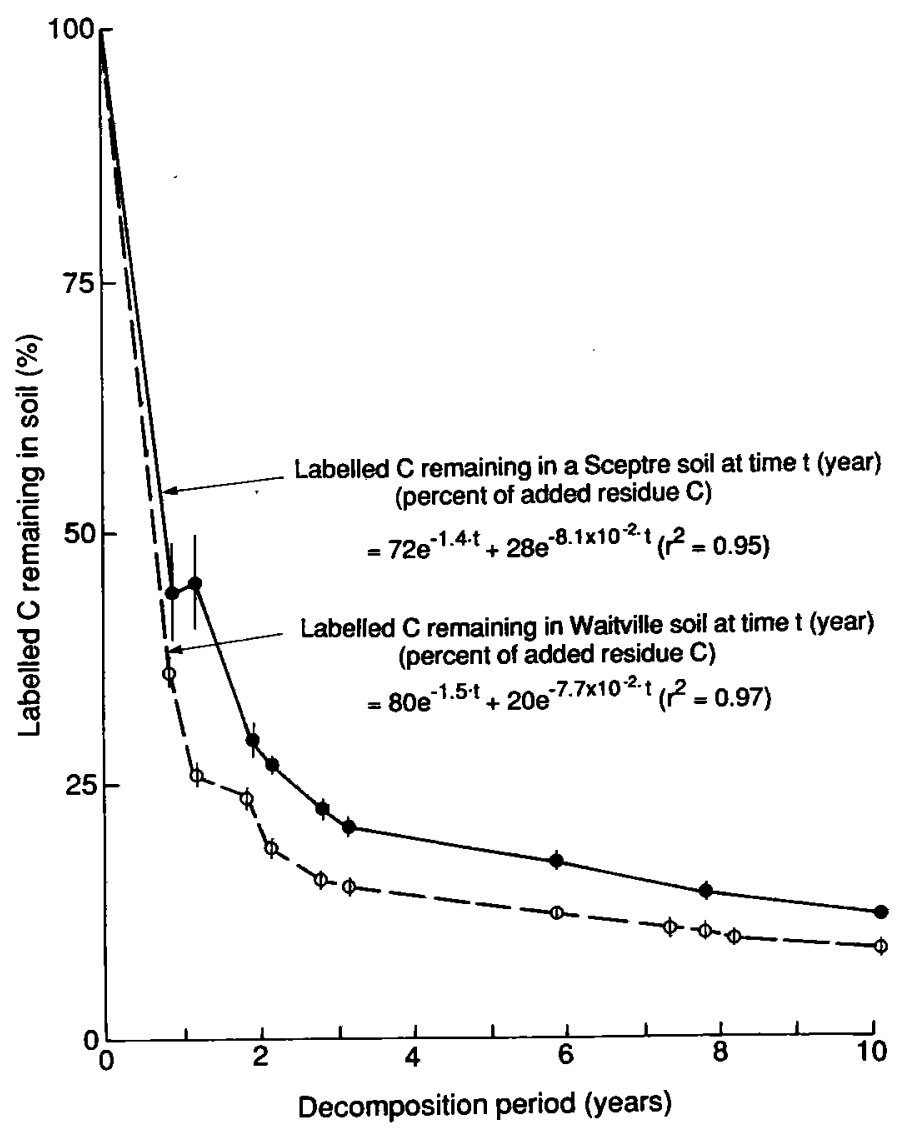

Fig. 1. Labelled $\mathrm{C}$ remaining in Sceptre clay and Waitville loam soils amended with ${ }^{14} \mathrm{C}-,{ }^{15} \mathrm{~N}-$ labelled wheat straw. Vertical lines represent standard errors of the means.

analysis of variance. Differences significant at the $95 \%$ level of probability or greater are noted.

\section{RESULTS}

\section{Ten-year Study}

MINERALIZATION OF LABELLED C. Labelled $\mathrm{C}$ added as wheat straw was rapidly mineralized in both soils (Fig. 1). During the initial period, residues mineralized more quickly in the Waitville loam, with $30 \%$ less labelled $\mathrm{C}$ remaining after $2 \mathrm{yr}$. This was attributed to the more moist environment, hence more intense biological activity at the Waitville site, as compared to that at Sceptre which experiences a drier summer.

Two components of net mineralization could be differentiated by mathematical analysis of the data. Seventy-two to eighty percent of the labelled $C$ was mineralized relatively quickly with $k=1.4 \mathrm{yr}^{-1}$ $\left(T_{1 / 2}=0.50 \mathrm{yr}\right)$ in the Sceptre soil and with $k=1.5 \mathrm{yr}^{-1}\left(T_{1 / 2}=0.46 \mathrm{yr}\right)$ in the Waitville soil. This relatively small difference may reflect the effect of climate. The Sceptre soil contains more clay than the Waitville, and may therefore have stabilized more of the microbial decomposition products formed during the first $2 \mathrm{yr}$. The labelled $\mathrm{C}$ remaining mineralized more slowly with $k=8.1 \times 10^{-2} \mathrm{yr}^{-1}\left(T_{1 / 2}=8.5 \mathrm{yr}\right)$ at the Sceptre site and with $k=7.7 \times 10^{-2} \mathrm{yr}^{-1}$ $\left(T_{1 / 2}=9.0 \mathrm{yr}\right)$ at the Waitville site. The 
Table 3. Disposition of labelled $\mathbf{N}$ derived from added wheat residues

\begin{tabular}{|c|c|c|c|c|c|c|}
\hline \multirow{2}{*}{$\begin{array}{c}\text { Decomposition } \\
\text { period } \\
(\mathrm{yr})\end{array}$} & \multicolumn{3}{|c|}{ Sceptre clay } & \multicolumn{3}{|c|}{ Waitville loam } \\
\hline & Crop & Soil & Unaccounted & Crop & Soil & Unaccounted \\
\hline \multicolumn{7}{|l|}{ July $1968(0)$} \\
\hline 0.84 & & 57.4 & & & 57.1 & \\
\hline 1.17 & 16.9 & 66.6 & 16.5 & 17.0 & 46.0 & 37.0 \\
\hline 2.17 & 3.3 & 48.0 & 31.8 & 4.0 & 35.4 & 43.6 \\
\hline 2.84 & & $\mathrm{ND} \dagger$ & & & 29.9 & \\
\hline 3.17 & 0.8 & 40.7 & 38.3 & 1.3 & 28.3 & 49.4 \\
\hline 3.84 & & 34.1 & & & ND & \\
\hline 4.17 & 0.6 & 32.3 & 46.1 & 0.5 & 26.1 & 51.1 \\
\hline 5.84 & & 26.6 & & & 20.6 & \\
\hline 7.34 & 0.4 & ND & & 0.5 & 17.9 & 58.8 \\
\hline 7.84 & & 19.7 & & & 16.5 & \\
\hline 8.34 & & ND & & 0.3 & ND & \\
\hline 9.34 & 0.3 & 17.7 & 60.3 & 0.3 & 14.4 & 61.7 \\
\hline 10.09 & 0.2 & 16.0 & 61.8 & 0.2 & 13.4 & 62.5 \\
\hline Total & $\overline{22.5}$ & & Total & $\overline{24.0}$ & & \\
\hline
\end{tabular}

$\dagger$ Not determined.

slightly slower decay rate for remaining $\mathrm{C}$ in the Waitville loam may indicate stabilization of $\mathrm{C}$ in chemically resistant forms, as distinct from clay-protected forms in the Sceptre clay.

DECOMPOSITION OF LABELLED N. Harvested grain and straw removed $17 \%$ of the added wheat straw $\mathrm{N}$ in the first cropping season in both soils (Table 3 ). Only $63 \%$ of the residual $\mathrm{N}$ was accounted for in the Waitville loam and $84 \%$ in the Sceptre clay, indicating that there had been substantial losses of labelled $\mathrm{N}$ from the plough layer soil. Part of the apparent low recovery of labelled $\mathrm{N}$ at the Waitville site may be attributed to the leaching of labelled $\mathrm{NO}_{3}{ }^{-}$below the surface soil $(15 \mathrm{~cm}$ depth): recovery of labelled $\mathrm{N}$ in the second and third harvested crops was much higher in the Waitville soil than in the Sceptre clay. Examination of the distribution of labelled $\mathrm{N}$ in the profile of the Waitville loam after three cropping seasons showed, however, that more than $96 \%$ was located in the plough layer soil (Shields 1972). Nevertheless, at that time, the labelled $\mathrm{N}$ in the soil and that recovered in the harvested crops accounted for only $51-62 \%$ of the added residue $N$.

The rate of loss of labelled $\mathrm{N}$ from the soils decreased after the initial flush: more labelled
$\mathrm{N}$ was retained in the Sceptre soil by the end of the study $-16 \%$ compared to $13 \%$ in Waitville soil. While labelled $\mathrm{N}$ recovered in the harvested crops accounted for $24 \%$ of that added to the Waitville soil and for slightly less in Sceptre soil, the total labelled $\mathrm{N}$ recovered at both sites (soil plus harvested crops) was similar.

The labelled $\mathrm{N}$ remaining in the Sceptre and Waitville soils and accounted for in harvested crops over $10 \mathrm{yr}$ in the field is shown in Fig. 2. The specific net decay rate constants of the residual labelled $\mathrm{N}$ components in the soil also reflected the enhanced rates of mineralization in the Waitville soil during the initial period, and greater stabilization during the remainder of the study.

MinERALIZATION OF WHEAT STRAW UNDER CROP AND FALLOW. The placement of wheat residues in the field during the third year of the study made possible an examination of the effects of one fallow period on the fate of residual $\mathrm{C}$ and $\mathrm{N}$. The treatment cropped to wheat during the first year retained $10 \%$ more of the labelled $\mathrm{C}$ in the soil than that fallowed (Table 4). Under similar management in subsequent years this difference gradually diminished. 


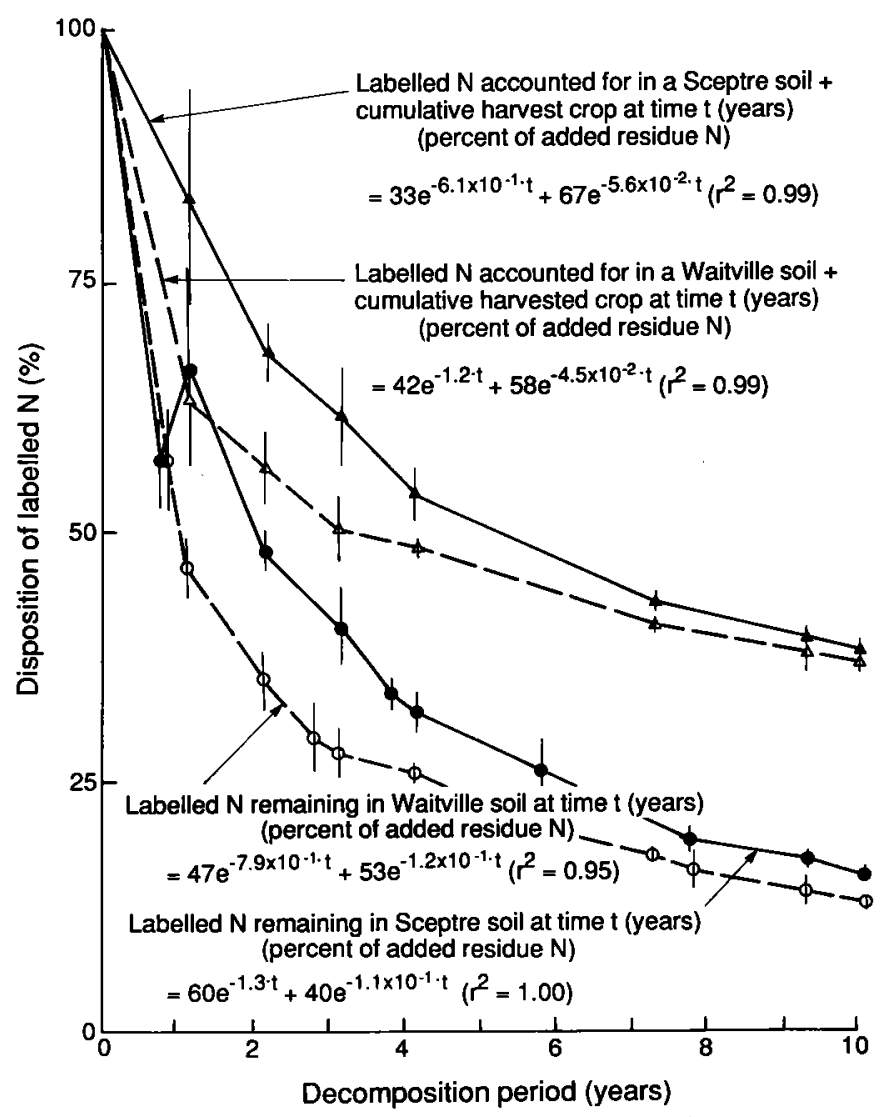

Fig. 2. Labelled $\mathrm{N}$ accounted for in harvested crops and remaining in Sceptre clay and Waitville loam soils amended with ${ }^{14} \mathrm{C}$-, ${ }^{15} \mathrm{~N}$ - labelled wheat straw. Vertical lines represent standard errors of the means.

Table 4. Effect of an initial fallow treatment on the subsequent mineralization of labelled $\mathrm{C}$ in a Sceptre clay

\begin{tabular}{ccc}
\hline $\begin{array}{c}\text { Decomposition } \\
\text { period } \\
(\mathrm{yr})\end{array}$ & \multicolumn{2}{c}{$\begin{array}{c}\text { Labelled C remaining in soil } \\
\text { (percent of added straw C) }\end{array}$} \\
\cline { 2 - 3 } Treatment $1 \dagger$ & Treatment 2† \\
\hline June $1971(0)$ & & \\
0.3 & 42.2 & 52.5 \\
1.2 & 31.0 & 36.2 \\
3.2 & 22.1 & 24.7 \\
4.2 & 19.4 & 21.0 \\
5.2 & 17.1 & 19.5 \\
6.2 & 15.8 & 17.4 \\
7.3 & 14.9 & 16.4 \\
\hline
\end{tabular}

$\dagger$ Fallow during the first season.

$\neq$ Cropped during the first season.
Data showing the disposition of labelled $\mathrm{N}$ in soil and in the harvested crop were not available for the first season but presumably a significant amount of the residual $\mathrm{N}$ (can be estimated at $17 \%$ based on the earlier study) was removed with the harvested crop. Notwithstanding, more labelled $\mathrm{N}$ was retained as soil organic $\mathbf{N}$ in the cropped treatment in the following spring (Table 5), but over twice as much labelled $\mathrm{N}$ was taken up subsequently by the crop growing on the soil previously fallowed. These data suggest that some of the mineralized labelled $\mathrm{N}$ had leached below the soil in the plough layer during fallow, to be 
Table 5. Comparison of the disposition of labelled $\mathrm{N}$ derived from microbial products and from wheat straw in a Sceptre clay

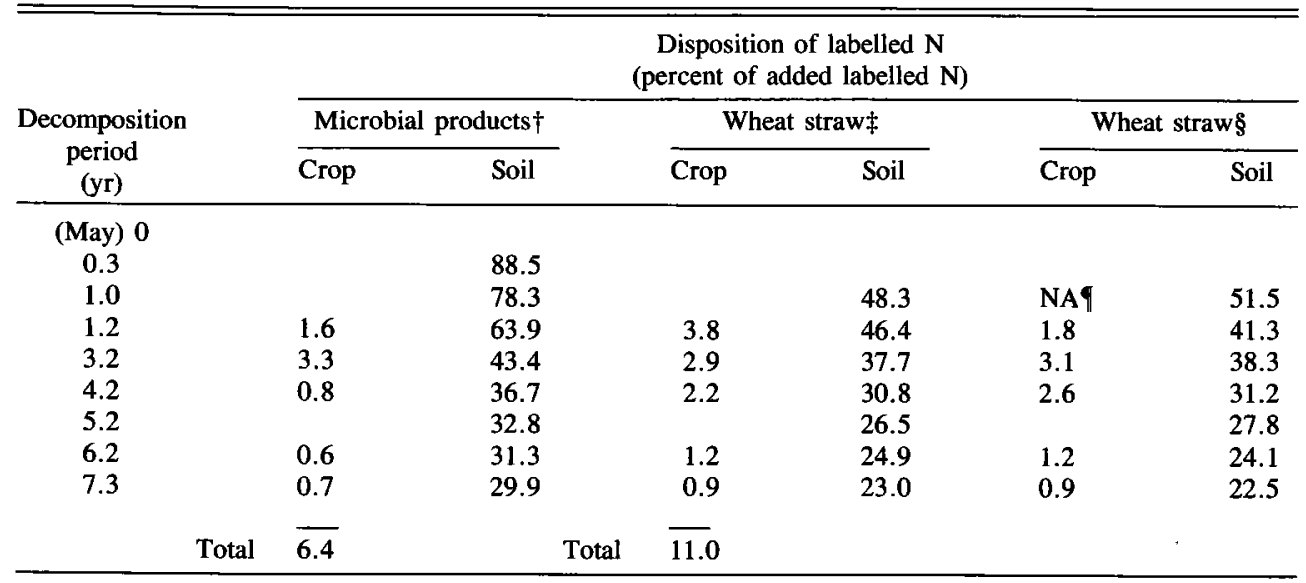

$\dagger$ Produced by an addition of glucose $+{ }^{15} \mathrm{~N}$-labelled $\mathrm{NH}_{4} \mathrm{NO}_{3}$.

Fallowed during the first season.

$\S$ Cropped during the first season.

I Data not available.

taken up by the crop in the second year. Thus, the fallow treatment drastically lowered the recovery of residual $\mathbf{N}$ in harvested crops.

STABILIZATION OF MICROBIAL PRODUCTS AND RESISTANT CONSTITUENTS OF PLANT RESIDUES. Crop residues are transformed into microbial biomass and other microbial products during decomposition. Therefore, $\mathrm{C}$ and $\mathrm{N}$ derived from added residues would be present as microbial compounds, undecomposed plant material and humic substances, making it difficult to differentiate between the decay rates of the various components. If it is assumed that the products of wheat straw degradation behave in the same way as those from glucose degradation, then the relative proportions of added $\mathrm{C}$ and $\mathrm{N}$ present as microbial products and plant materials can be determined by comparison of the net decay curves of $\mathrm{C}$ and $\mathrm{N}$ derived from wheat straw with those derived from the decay of microbial material (Fig. 3). All of the glucose $C$ was assimilated within the first 2-3 d with concomitant production of microbial biomass. The subsequent decay of $\mathrm{C}$ would represent the mineralization of microbial products.

Initially, labelled $\mathrm{C}$ derived from glucose was mineralized at a higher rate than the $\mathrm{C}$ derived from straw; $8 \%$ more labelled $\mathrm{C}$ remained in the straw-amended soil by the end of the first season. However, by the end of the second season slightly more labelled $\mathrm{C}$ remained in the glucose-amended soil, indicating a higher rate of mineralization of labelled $C$ in the wheat-straw-amended treatment. Although the majority of the stabilized $C$ in the wheat-straw-amended soil would be in microbial products, a small portion of this residual $\mathrm{C}$ may have been present in undecomposed plant constituents such as lignin, so that the microbial $\mathrm{C}$ produced from glucose must have been slightly more stable than the labelled $\mathrm{C}$ remaining from wheat straw. Furthermore, both amendments left a similar fraction of their carbon in the stabilized $\mathrm{C}$ component, indicating that the turnover times of the microbial materials derived from crop residues and from glucose were similar.

In the glucose-amended soil, labelled $\mathrm{NH}_{4} \mathrm{NO}_{3}$ was rapidly immobilized during the initial period, with labelled organic $\mathrm{N}$ accounting for about $90 \%$ of the mineral ${ }^{15} \mathrm{~N}$ originally added. It was observed that almost all of the labelled $\mathbf{N}$ was recovered in the fallow treatment whereas up to $20 \%$ was 


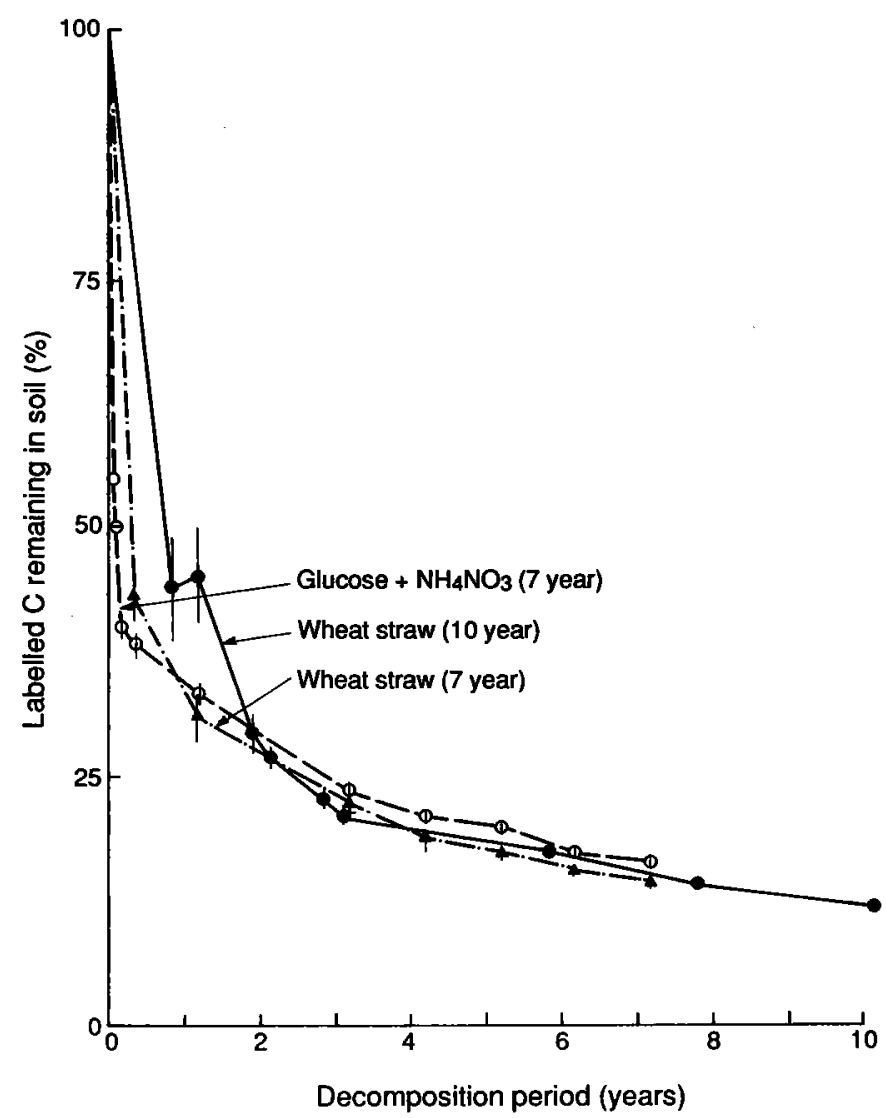

Fig. 3. Labelled $\mathrm{C}$ remaining in a Sceptre clay amended with ${ }^{14} \mathrm{C}$-labelled glucose $+{ }^{15} \mathrm{NH}_{4}{ }^{15} \mathrm{NO}_{3}$ and with ${ }^{14} \mathrm{C}$-, ${ }^{15} \mathrm{~N}$-labelled wheat straw. Vertical lines represent standard errors of the means.

Table 6. Disposition of labelled $\mathrm{N}$ derived from microbial products (glucose $+\mathrm{NH}_{4} \mathrm{NO}_{3}$ amendment) in a cropped and a fallowed Sceptre soil after one season

\begin{tabular}{|c|c|c|c|}
\hline \multirow{3}{*}{$\begin{array}{l}\text { Soil depth } \\
\text { (cm) }\end{array}$} & \multicolumn{3}{|c|}{$\begin{array}{c}\text { Disposition of labelled } \mathrm{N} \\
\text { (percent of added } \mathrm{NH}_{4} \mathrm{NO}_{3} \text { ) }\end{array}$} \\
\hline & \multirow{2}{*}{$\frac{\text { Fallowed }}{\text { Soil }}$} & \multicolumn{2}{|c|}{ Cropped } \\
\hline & & Soil & Crop \\
\hline $0-12$ & 88.5 & 76.3 & 4.6 \\
\hline $12-30$ & 5.2 & $\mathrm{ND}_{\dagger}^{\dagger}$ & \\
\hline $30-40$ & 1.2 & ND & \\
\hline $40-56$ & 0.5 & ND & \\
\hline $56-71$ & 0.5 & ND & \\
\hline \multirow[t]{2}{*}{$71-86$} & 0 & ND & \\
\hline & 95.9 & \multicolumn{2}{|c|}{80.9} \\
\hline
\end{tabular}

$\dagger$ Not determined. 
unaccounted for in the cropped treatment (Table 6). Most of the labelled $\mathrm{N}$ remaining was retained in the surface soil in both treatments although $7.4 \%$ had been leached below $12-\mathrm{cm}$ depth in the fallowed soil. Less than $2 \%$ of the labelled organic $\mathrm{N}$ was mineralized in the fallowed soil during the first season (Shields 1972). Labelled inorganic $N$ not immobilized with the glucose amendment would therefore have supplied most of the labelled $\mathrm{N}$ taken up by the plants in the cropped treatment.

In total, $11 \%$ of the added labelled $\mathrm{N}$ was recovered in the harvested crops in the strawamended treatment whereas only $6.4 \%$ was recovered from the labelled $\mathrm{N}$ supplied by microbial products (Table 5). Soil $\mathrm{N}$ accounted for more of the added labelled $\mathrm{N}$ in the glucose $+\mathrm{NH}_{4} \mathrm{NO}_{3}$ amended treatment compared to that in the straw-amended treatment. Substantial losses of labelled N from the soil were evident within the first year especially in the straw-amended soil where less than $50 \%$ of the labelled $\mathrm{N}$ was accounted for; $64-66 \%$ was unaccounted for in both treatments by the end of the study.

\section{DISCUSSION}

The general use of first-order rate kinetics (Hunt 1977; Jenkinson and Rayner 1977; Paul and van Veen 1978; van Veen and Paul 1981) for mathematical descriptions of organic matter decomposition in soils implies that the biological potential of soil is not rate limiting at any time (van Veen et al. 1981). The lag times involved in substrate invasion and microbial growth would be short due to: (1) the large size of the microbial population relative to the amount of substrate added, and (2) to its rapid growth rate. Most field studies, however, have not recorded local climatic conditions or sampled at short enough time intervals to obtain an adequate measurement of the kinetics of decomposition during the early rapid period.

Double exponential equations gave a good fit to data describing the net decomposition of plant residues under field conditions over the 1- to 10-yr time span. The justification for fitting decomposition data to such a simple model are: (1) the kinetic analysis of decay curves (Jenkinson 1977b), and (2) differentiation based on the architecture and chemical complexity of the constituents in the substrate (Juma and McGill 1985). The major components in plant and microbial cells can be partitioned between labile, cytoplasmic material and resistant, structural (cell walls) material. During decomposition, added organic material undergoes rapid chemical and physical transformations into soil humic material which is slowly decomposable. However, the simple two-compartment exponential decay model, although providing a useful description of the decay-time curve over an appreciable part of its range, is an oversimplification of the true nature of the decomposition process (Ladd et al. 1985). The model is unsatisfactory because it does not take into account: (1) the formation and decay of the microbial biomass (Clark and Paul 1970), (2) the production of stable organic matter (Campbell et al. 1977), (3) the inhibition or enhancement of decomposition of some substances in the presence of others (Lewis and Starkey 1968; Kirk et al. 1976), and (4) decomposition conforming to kinetics other than first-order reaction rates.

Net mineralization rates of $\mathrm{C}$ during the slow decomposition phase (about 2-10 yr) were similar at different locations in temperature regions (Table 7). Turnover of the stabilized C (comprising living biomass, microbial products and stabilized plant components) was only marginally affected by the vast differences in climate at these sites during this phase of decomposition. Furthermore, different management treatments during the first year did not alter the mineralization of crop residue $\mathrm{C}$ and $\mathbf{N}$ in the long term. For example, although cropping slowed the rate of $\mathrm{C}$ and $\mathrm{N}$ mineralization over the first growing season, the cropped treatment eventually caught up with the fallowed treatment. It appears that chemical reactions with soil organic and inorganic constituents and physical protection dominated the long-term rates of mineralization of $\mathrm{C}$ and $\mathrm{N}$ derived from crop residues. 
Table 7. Long-term net mineralization rates of plant residues

\begin{tabular}{|c|c|c|c|c|}
\hline \multirow{2}{*}{$\begin{array}{l}\text { Plant } \\
\text { residues }\end{array}$} & \multirow[b]{2}{*}{ Location } & \multicolumn{2}{|c|}{$T_{1 / 2}(\mathrm{yr})$} & \multirow[b]{2}{*}{ References } \\
\hline & & $\mathrm{C}$ & $\mathbf{N}$ & \\
\hline Wheat straw & Saskatchewan & $8.5-9$ & $12.4-15.4$ & This study \\
\hline Medic & Australia & 8.4 & 10.7 & Ladd et al. (1981) \\
\hline Wheat straw & West Germany & $5.5-6$ & & $\begin{array}{l}\text { Sauerbeck and } \\
\text { Gonzalez (1977) }\end{array}$ \\
\hline Ryegrass & England & 8 & & Jenkinson (1977b) \\
\hline
\end{tabular}

Only a minor portion of added C (20-30\%), whether it came directly from crop residues or from microbial biomass, eventually became stabilized soil organic matter. This input of $\mathrm{C}$ is critical in the long term for maintenance of both soil organic matter and soil fertility. Furthermore, practices which enhance the return of plant residues to soil can play a major role in the development of soil structure and thus promote soil conservation (Black 1973). The processes controlling stabilization of organic material in soil, especially the turnover of the soil microbial biomass, need further study (Jenkinson and Ladd 1981; Ladd et al. 1985).

Work with tracers has verified that large amounts of labelled phenolic compounds are incorporated directly into stabilized humus, whereas nonaromatic materials are incorporated into the soil microbial biomass (Kassim et al. 1982). ${ }^{14} \mathrm{C}$-labelled melanic fungal residues were very slowly degraded and accumulated, mainly as partly degraded cell walls, in the humin fraction of soil organic matter. In this study, the $\mathrm{C}$ remaining after $7 \mathrm{yr}$ in the field following a glucose amendment was more stable than $\mathrm{C}$ derived from wheat straw, verifying van Veen and Paul's (1981) suggestion that some of the straw components such as lignin are degraded faster than microbial products which would include melanic products (Martin et al. 1982).

Fine clays have been found to exert a stabilizing effect on microbial degradation of proteinaceous materials and polysaccharides (Sorensen 1975, 1981). This was evident when the pattern of decomposition in the Sceptre soil (clay) was compared to that in the Waitville soil. Soil clays play a particularly important role in stabilizing substrates in the intermediate turnover time range $\left(T_{1 / 2}=1-4 \mathrm{yr}\right.$ ) (Anderson and Paul 1984). In our experiments, decomposition rates would have been influenced by soil differences and by climatic differences: to separate these effects it would have been necessary to incubate under controlled laboratory conditions.

Ladd et al. (1981b) reported that wheat plants took up $10.9-17.3 \%$ of the labelled $N$ derived from the amendment of medic tissues. In our study, recovery of added $\mathrm{N}$ in harvested grain and straw during the first cropping season gave similar values (Table 3). These data indicate that mineralized labelled organic $\mathrm{N}$ was used with $32-51 \%$ efficiency, comparable to values reported for chemical fertilizer $\mathrm{N}$ applications (Paul and Rennie 1977). In the crop year following the first fallow period, however, plants apparently used mineralized labelled $\mathrm{N}$ with an efficiency of only 7\% (Table 5). Mineralized crop residue $\mathbf{N}$ is subject to losses from the surface soil by leaching and by denitrification. There was evidence of leaching at the Waitville site during the initial 3 yr of the study. Mineralized $\mathrm{N}$ could have leached beyond the rooting zone during the first season when the soil was in fallow, thus becoming permanently out of reach to cereal crops (Campbell et al. 1975).

Amato, M., Jackson, R. B., Butler, J. H. A. and Ladd, J. N. 1984. Decomposition of plant material in Australian soils. II. Residual organic ${ }^{14} \mathrm{C}$ and ${ }^{15} \mathrm{~N}$ from legume plant parts decomposing under field and laboratory conditions. Aust. J. Soil Res. 22: 331-341.

Amato, M. and Ladd, J. N. 1980. Studies of nitrogen immobilization and mineralization in calcareous soils. V. Formation and distribution of isotope-labelled biomass during decomposition of 
${ }^{14} \mathrm{C}$ - and ${ }^{15} \mathrm{~N}$-labelled plant material. Soil Biol. Biochem. 12: 405-411.

Anderson, D. W. and Paul, E. A. 1984. Organomineral complexes and their study by radiocarbon dating. Soil Sci. Soc. Am. J. 48: 298-301.

Biederbeck, V. O. 1966. The use of ${ }^{14} \mathrm{C}$-labelled plant material to measure the turnover of organic residues in soil. M.Sc. Thesis, University of Saskatchewan, Saskatoon, Sask.

Black, A. L. 1973. Soil properties associated with crop residue management in a wheat-fallow rotation. Soil Sci. Soc. Am. Proc. 37: 943-946.

Bremner, J. M. 1965. Total nitrogen. Pages 1149-1178 in C. A. Black ed. Methods of soil analysis. Agronomy no. 9. Am. Soc. Agron., Madison, Wis.

Campbell, C. A., Nicholaichuk, W. and Warder, F. G. 1975. Effect of a wheat-summer fallow rotation on subsoil nitrate. Can. J. Soil Sci. 55: 279-286.

Campbell, C. A., Paul, E. A., Rennie, D. A. and McCallum, K. J. 1967. Applicability of the carbon-dating method of analysis to soil humus studies. Soil Sci. 104: 217-224.

Chapman, L. J. and Brown, D. M. 1966. The climates of Canada for agriculture. The Canada Land Inventory, Report No. 3.

Christensen, B. T. 1986. Barley straw decomposition under field conditions: effect of placement and initial nitrogen content on weight loss and nitrogen dynamics. Soil Biol. Biochem. 18: 523-529.

Clark, F. E. and Paul, E. A. 1970. The microflora of grassland. Adv. Agron. 22: 375-436. Fuhr, F. and Sauerbeck, D. 1968. Decomposition of wheat straw in the field as influenced by cropping and rotation. Pages 241-250 in Isotopes and radiation in soil organic matter studies. FAO/IAEA, Vienna, Austria.

Herman, W. A., McGill, W. B. and Dormaar, J. F. 1977. Effects of initial composition on decomposition of roots of three grass species. Can. J. Soil Sci. 57: 205-215.

Hunt, H. W. 1977. A simulation model for decomposition in grasslands. Ecology 58: 469 484 .

Jenkinson, D. S. 1965. Studies on the decomposition of plant material in soil. 1. Losses of carbon from ${ }^{14} \mathrm{C}$-labelled ryegrass incubated with soil in the field. J. Soil Sci. 16: 104-115.

Jenkinson, D. S. 1971. Studies on the decomposition of ${ }^{14} \mathrm{C}$-labelled organic matter in soil. Soil Sci. 111: 64-70.

Jenkinson, D. S. 1977a. Studies on the decomposition of plant material in soil. IV. The effect of rate of addition. J. Soil Sci. 28: 417-423. Jenkinson, D. S. 1977b. Studies on the decomposition of plant material in soil. V. The effects of plant cover and soil type on the loss of carbon from ${ }^{14} \mathrm{C}$-labelled ryegrass decomposing under field conditions. J. Soil Sci. 28: 424-434.

Jenkinson, D. S. and Ladd, J. N. 1981. Microbial biomass in soil: measurement and turnover. Pages 415-471 in E. A. Paul and J. N. Ladd, eds. Soil biochemistry, Vol. 5. Marcel Dekker, Inc., New York, N.Y.

Jenkinson, D. S. and Rayner, J. H. 1977. The turnover of soil organic matter in some of the Rothamsted classical experiments. Soil Sci. 123: 298-305.

Jenkinson, D. A. and Ayanaba, A. 1977. Decomposition of carbon-14 labelled plant material under tropical conditions. Soil Sci. Soc. Am. J. 41: 912-915.

Jenkinson, D. S. and Tinsley, J. 1959. Studies on the organic material extracted from soils and compost. 1 . The isolation and characterization of lingo-proteins from compost. J. Soil Sci. 10: 245-263.

Juma, N. G. and McGill, W. B. 1985. Decomposition and nutrient cycling in agro-ecosystems. Pages 74-136 in M. J. Mitchell and J. P. Nakas, eds. Microfloral and faunal interactions in natural and agro-ecosytems. Martinus Nijhoff/Dr. W. Junk Publ., Amsterdam, The Netherlands.

Kassim, G., Stott, D. E., Martin, J. P. and Haider, K. 1982. Stabilization and incorporation into biomass of phenolic and benzenoid carbons during biodegradation in soil. Soil Sci. Soc. Am. J. 46: 305-309.

Kirk, T. K., Conners, W. J. and Zeikus, J. G. 1976. Requirement for a growth substance during lignin decomposition by two woodrotting fungi. Appl. Environ. Microbiol. 32: 192-194.

Ladd, J. N., Amato, M. and Oades, J. M. 1985. Decomposition of plant material in Australian soils. III. Residual organic and microbial biomass $\mathbf{C}$ and $\mathrm{N}$ from isotype-labelled legume material and soil organic matter, decomposing under field conditions. Aust. J. Soil Res. 23: 603-611.

Ladd, J. N., Jackson, R. B., Amato, M. and Butler, J. H. A. 1983. Decomposition of plant material in Australian soils. 1. The effect of quantity added on decomposition and on residual microbial biomass. Aust. J. Soil Res. 21: 563-570.

Ladd, J. N., Oades, J. M. and Amato, M. 1981. Microbial biomass formed from ${ }^{14} \mathrm{C},{ }^{15} \mathrm{~N}$-labelled 
plant material decomposing in soils in the field. Soil Biol. Biochem. 13: 119-126.

Lespinat, P. A., Hetier, J. M., Thomann, C. and Chone, T. 1976. Use of maize residues uniformly labelled with ${ }^{14} \mathrm{C}$ in the study of organic matter of an Andosol, brown soil and a ferrallitic soil. Sci. Sol. 1: 53-66.

Lewis, J. A. and Starkey, R. L. 1968. Vegetable tannins, their decomposition and effects on decomposition of some organic compounds. Soil Sci. 106: 241-247.

Martin, J. P., Zumino, H., Peirano, P., Caiozzi, M. and Haider, K. 1982. Decomposition of ${ }^{14} \mathrm{C}$ labelled lignins, model humic acid polymers, and fungal melanins in allophanic soils. Soil Biol. Biochem. 14: 289-293.

McGill, W. B. 1971. Turnover of microbial metabolites during nitrogen mineralization and immobilization in soil. Ph.D Thesis, University of Saskatchewan, Saskatoon, Sask.

McKeague, J. A. 1976. Manual on soil sampling and methods of analysis. Soil Research Institute of Canada Publ., Agriculture Canada, Ottawa, Ont. Oberlander, H. E. 1973. The fate of organic manures in soil as traced by means of radiocarbon. Pontificiae Academiae Scientiarum Scripta Varia No. 38.

Oberlander, H. E. and Roth, K. 1968. Transformation of ${ }^{14} \mathrm{C}$-labelled plant material in soils under field conditions. Pages 251-262, in Isotopes and radiation in soil organic matter studies. FAO/IAEA, Vienna, Austria.

Parr, J. F. and Papendick, R. I. 1978. Factors affecting the decomposition of crop residues by microorganisms. Pages 101-129 in W. R. Oschwald, ed. Crop residue management systems. Am. Soc. Agron., Madison, Wis. Publ. 31.

Paul, E. A. and van Veen, J. A. 1978. The use of tracers to determine the dynamic nature of organic matter. Trans. 11th Int. Congr. Soil Sci., Edmonton, Alta. pp. 61-102.

Paul, E. A. and Rennie, D. A. 1977. Crop utilization and fate of fertilizer nitrogen in soil. Pages 177-185 in Proc. 1977 Soil fertility and crop workshop soil management S10, Publ. No. 328, Ext. Div. University of Saskatchewan, Saskatoon, Sask. Porter, L. K. and O'Deen, W. A. 1977. Apparatus for preparing nitrogen from ammonium chloride for nitrogen-15 determinations. Anal. Chem. 49: 514-516.

Reber, H. and Schara, A. 1971. Degradation sequences in wheat straw extract inoculated with soil suspensions. Soil Biol. Biochem. 3: 381-383.
Ross, P. J. and Martin, A. E. 1970. A rapid procedure for preparing gas samples for nitrogen-15 determination. Analyst 95: 817-822. Sauerbeck, D. and Fuhr, F. 1968. Alkali extraction and fractionation of labelled plant material before and after decomposition - a contribution to the technical problems in humification studies. Pages 3-12 in Isotopes and radiation in soil organic matter studies. GAO/IAEA, Vienna, Austria.

Sauerbeck, D. and Gonzalez, M. A. 1977. Field decomposition of ${ }^{14} \mathrm{C}$ labelled plant residues in various soils of the Federal Republic of Germany and Costa Rica. Pages 159-170 in Soil organic matter studies, FAO/IAEA, Vienna, Austria.

Sauerbeck, D. R., Hohnen, B. and Massen, G. G. 1972. De Abbau von ${ }^{14}$ C-markiertem Pfanzernmaterial in verschiedenen Boden. Agrochimica 16: 62-76.

Shields, J. A. 1972. Turnover of organic carbon in soil organisms and plant residues. Ph.D. Thesis, University of Saskatchewan, Saskatoon, Sask.

Shields, J. A. and Paul, E. A. 1973. Decomposition of ${ }^{14} \mathrm{C}$-labelled plant material under field conditions. Can. J. Soil Sci. 53: 297-306.

Smith, J. H. and Douglas, C. L. 1971. Wheat straw decomposition in the field. Soil Sci. Soc. Am. Proc. 35: 269-272.

Sorensen, L. H. 1976. Duration of amino acid metabolites formed in soils during decomposition of carbohydrates. Soil Sci. 104: 234-241.

Sorensen, L. H. 1975. The influence of clay on the rate of decay of amino acid metabolites synthesized in soils during decomposition of cellulose. Soil Biol. Biochem. 7: 171-177.

Sorensen, L. H. 1981. Carbon-nitrogen relationships during the humification of cellulose in soils containing different amounts of clay. Soil Biol. Biochem. 13: 313-321.

Stott, D. E., Kassim, G., Martin, J. P. and Haider, K. 1983. Stabilization and incorporation into biomass of specific plant carbons during biodegradation in soils. Plant Soil 70: 15-26.

Van Veen, J. A. and Paul, E. A. 1981. Organic C dynamics in grassland soils. 1. Background information and computer simulation. Can. J. Soil Sci. 61: 85-201.

Van Veen, J. A., MeGill, W. B., Hunt, H. W., Frissel, M. J. and Cole, C. V. 1981. Simulation models of the terrestrial nitrogen cycle. Pages 25-48 in F. E. Clark and T. Rosswall, eds. Terrestrial nitrogen cycle. Processes, ecosystems strategies and management impacts. Ecol. Bull. Stockholm, 33, Sweden. 
Waksman, S. A. and Tenny, F. G. 1927. The composition of natural organic materials and their decomposition in the soil: II. Influence of age of plant upon the rapidity and nature of its decomposition-rye plants. Soil Sci. 24: 317-333.
Wang, T. S. C., Wang, M. C., Ferng, Y. L. and Huang, P. M. 1983. Catalytic synthesis of humic substances by natural clays, silts and soils. Soil Sci. 135: 350-360. 